\title{
O MAL E OS MALVADOS: AS CRENÇAS POLIDEMONISTAS NA IGREJA UNIVERSAL DO REINO DE DEUS
}

\author{
Airton Luiz Jungblut
}

O texto "O simulacro da alteridade: uma análise discursiva do ritual de exorcismo da Igreja Universal do Reino de Deus" de Jaçanã Ribeiro apresenta uma proposta bastante original para a análise dessa igreja neopentecostal. Com ferramentas conceituais da Análise de Discurso o autor faz emergir analiticamente elementos interessantes da já paradigmática relação antagônica entre a IURD e as chamadas religiōes afro-brasileiras. O tratamento proposto pelo autor, sobretudo o recurso à noção de simulacro, efe tivamente joga luzes inusitadas sobre essa curiosa apropriação vilipendiadora que a IURD faz do repertório simbólico "afro".

A título de reação ao texto, não vou me deter na avaliação da pertinência destes exercícios analíticos que julgo bem sucedidos, mas sim em algumas das interpretações etnográficas que servem de base para a análise realizada. Devo dizer que assim procedendo não estarei, o tempo inteiro, dialogando criticamente apenas com o autor deste texto, mas, sobretudo, com algumas leituras sobre a IURD por ele assumidas que já se cristalizaram nas vozes de vários pesquisadores.

Em primeiro lugar, é importante dizer que, ao se caracterizar identitariamente a IURD e o neopentecostalismo brasileiro que a contém, não se deve exagerar na distintividade atribuída ao combate feito à figura do Diabo. Longe de ser um traço emblemático exclusivo da IURD ou do neopentecostalismo essa ênfase na "guerra espiritual" contra os intentos

${ }^{1}$ Professor e pesquisador junto ao Programa de Pós-Graduação em Ciências Sociais da Pontifícia Universidade Católica do Rio Grande do Sul (PUCRS).

Debates do NER, Porto Alegre, ano 6, N. 7, P. 125-133, JAn./Jun. 2005 
satânicos neste mundo é algo que atinge transversalmente áreas muito extensas do campo evangélico brasileiro e mundial. $\mathrm{O}$ combate ferrenho a Satanás têm adeptos por todo continuum que vai de setores do protestantismo histó rico mais circuns peto até as ma is barulhentas agências neopentecostais de cura divina. Já não é de hoje que por quase todas as denominações evangélicas se pode encontrar exasperados militantes antisatã dispostos a exorcismos, oraçóes fortes, jejuns, proselitismo agressivo, "evangelismo de libertação", etc. tudo em nome de vitórias cotidian as contra o príncipe do mal. $\mathrm{O}$ que, portanto, parece ser um sinal identitário exclusivo da IURD, ou do neopentecostalismo brasileiro, não o é tanto quanto se julga.

Em segundo lugar, também é oportuno uma reflexão sobre o papel do repertório simbólico das religiōes afro-brasileiraspara a constituição da identidade da IURD. Esse exercício de construção de equivalência entre demônios e entidades afro aparece no texto de Jaçanã Ribeiro como algo que fornece a base fundamental sobre a qual está assentada a identidade dessa igreja. A IURD, como sugere o autor, amparado em outros pesquisadores, seria a expressão institucionalizada de um "neopentecostalismo macumbeiro" o que significa que ela seria extremamente dependente, para existir enquanto uma identidade peculiar, do repertório simbólico das vítimas de seus ataques. A IURD, nessa visão, viveria uma espécie de parasitismo identitário já que dependeria enormemente das pilhagens identitárias que realiza junto às religiôes afro-brasileiras para poder ostentar aqueles traços diacríticos que, maniqueisticamente invertidos, são tão caros a sua imagem no mercado religioso brasileiro.

Por mais que se possa dizer que é isso que efetivamente ocorre em muitos dos exercícios identitários realizados pela IURD, está incorreto, ao meu ver, atribuir importância fundamental a tal parasitismo identitário para com as religiōes afro. O equívoco residiria no fato de se desconsiderar, ou não se dar a devida importância ao fato, que a IURD não elege somente as entidades afro como alvo de seus ataques. Embora sejam essas entidades a merecer uma maior visibilidade nos discursos anti-satânicos dessa igreja não podemos nos esquecer que outras modalidades religiosas (catolicismo,

Debates do NER, Porto Alegre, ano 6, N. 7, P. 125-133, jan./Jun. 2005 
espiritismo, esoterismo, etc.), e suas respectivas divindades, são, também, atacadas. Basta lembrar, por exemplo, o episódio conhecido como o "chute na santa" ocorrido no dia 12 de Outubro de 1995, dia de Nossa Senhora, tida como a "padroeira do Brasil" pelos católicos. Neste dia uma estátua dessa santa foi literalmente chutada por um bispo da IURD durante a transmissão do programa "Palavra de Vida", pela TV Record. Cabe lembrar que para os agentes dessa igreja os santos católicos - assim como os espíritos desencarnados do Espiritismo e os avatares do Movimento Nova Era - são considerados demônios a serviço de Satanás. ${ }^{2}$

Poderia-se contra-argumentar que isso é residual e que, embora essas entidades não sejam desconsideradas, elas não têm a mesma importância que as pomba-giras, exus e orixás como alvos da performática ira anti-satânica da IURD. Mas, o que dizer, então, daqueles contextos onde a IURD não se depara com uma cultura em que tais entidades afro são familiares?

Em a "Igreja Universal do Reino de Deus: os novos conquistadores da fé", obra organizada por Oro, Corten \& Dozon (que, inclusive, consta na bibliografia utilizada por Jaçanã Ribeiro), estão descritos contextos onde a IURD é obrigada a antagonizar com outras forças religiosas: o culto aos mortos no Japão (Freston, 2003, p. 219); a idolatria hinduísta na Índia (Idem, ibidem, p. 223); os curandeiros, o “"mal de ojo" e os feitiços na Argentina (Seman, 2003, p. 74); o culto à Virgem de Guadalupe no México (tida como "u ma imagem demoníaca coberta de ouro") (Doran, 2003, p. 99); as testemunhas de Jeová, a Nova Era e religiões orientalizadas em Portugal: (Mafra, 2003, p.173).

Ora, fica evidente, então, que o repertório afro é apenas um dos campos onde o antagonismo da IURD é exercitado. Resulta, portanto, problemática toda tentativa de atribuir importância fundamental às contendas com as religiōes afro-brasileiras para a identidade desta igreja. Os exus, pombagiras, caboclos, orixás e mais recentemente os "encostos", embora

${ }^{2}$ Em outro texto (Jungblut, 2005) analiso, de forma mais detalhada, a construção da identidade religiosa da IURD no contraste antagônico que esta estabelece com outros grupos religiosos. 
insinuem-se como elementos simbólicos fundamentais para a IURD se definir como combatedora ferrenha do mal satânico, só o são num dos fronts onde essa igreja atua, no Brasil.

Quando falei, acima, que o combate ferrenho ao Diabo não é algo que possa ser considerado traço unicamente caracterizador da IURD, e mesmo do neopentecostalismo brasileiro, tinha em mente as relaçôes deste antisatanismo,aparentemente autóctone em sua fórmula, com a chamada "Doutrina dos Espíritos Territorias". Em outro texto, também publicado nos Debates do NER (Jungblut, 2003, p. 38-39) fiz referência à difusão no Brasil desta doutrina de origem norte-americana. Explicava, naquela ocasião, tratar-se basicamente de uma crença que postula que a ação dos espíritos que serviriam a Satanás no mundo humano dar-se-ia a partir de uma lógica segundo a qual determinados demônios a ele submetidos, ou legióes deles, teriam um tipo de autoridade circunscrita a domínios geográficos precisos e neles agiriam de forma contextualizada, segundo as tradições histórico-culturais locais. Assim, é missão dos crentes que pretendem "libertar" determinado lugar da dominação satânica operar um "mapeamento espiritual" de cidades, países, regiōes e até continentes, buscando iden tificar que tipo de entidades demoníacas ali dominam e como essa dominação é mágico-ritualmente mantida. Trata-se de fazer um inventário - que pode até mesmo se valer de estudos históricos, arqueológicos e antropológicos para buscar no passado ou no presente as causas de tais domínios demoníacos. Nesses inventários considera-se coisas como: crenças e rituais locais que reatualizariam o domínio demoníaco, fatos históricos relacionados com a colonização de uma região ou a fundação de uma cidade que teriam contribuído para tal domínio, possível ligação dos líderes locais com práticas explicitamente satânicas etc. A ação de "libertação", diz-se, se quiser ser eficaz, deve estar embasada num quadro informativo o mais completo possível a respeito de que tipo de entidades malignas ali agem e através de que elementos mágico-religiosos elas perpetuam seu domínio sobre o local.

Nesta doutrina, como se pode ver, está implícita uma noção de endemoniamento coletivo no qual o indivíduo não cristão, por residir em determinado lugar ou fazer parte de determinada coletividade (nação, etnia, 
etc.), não tem uma real autonomia, já que somente pode realizar a vontade dos demônios que dominam a região. Libertar um local geográfico ou coletividade de tais dominaçóes demoníacas é uma tarefa que visa restituir alguma autonomia aos indivíduos dali, autonomia essa que só se realiza totalmente quando estes tornam-se cristãos, vivem um "novo nascimento", e, assim, tornam-se livres (ou mais resistentes), tanto em relação às coerções satânicas exercidascoletivamente quanto das açōes individualizadas exercidas por Satanás e seus demônios sobre a vida de cada um. ${ }^{3}$

Torna-se, ao meu ver, necessário ter em vista a difusão dessa doutrina no campo evangélico brasileiro para que não tomemos uma influência alóctone por uma invenção autóctone. É sempre importante lembrar que algumas das características teológicas do nosso neopentecostalismo brasileiro são tão somente adaptaçoôes ou, simplesmente, adoções de tendências norte-americanas. O caso da IURD, nesse sentido, é até interessante se comparado à também neopentecostal Igreja Internacional da Graça de Deus (IIGD). Diferentemente dessa concorrente, a IURD, ao assimilar doutrinas norte-americanas, como a "Guerra Espiritual”, "Teologia da Prosperidade" e a "Doutrina dos Espíritos Territoriais", não "recon hece os créditos", ou seja, não faz menção aos criadores originais dessas posturas teológicas. A IIGD, pelo contrário, e mais visivelmente em relação à "Teologia da Prosperidade", não só reconhece tais influencias norte-americanas como publica e distribui a bibliografia que difunde suas bases teológicas ${ }^{4}$.

No caso da IURD, ao meu ver, por trás de toda a performance antagonística empregada por essa igreja em seus ataques as entidades afrobrasileiras, subjaz uma compreensão da ação de Satanás sobre o mundo tomada de empréstimo da "Doutrina dos Espíritos Territoriais". O privilé-

${ }^{3}$ Para uma melhor compreensão da "Dou trina dos Espíritos Ter ritoriais" é preciso recorrer à bibliografia evangélica. Uma sugestão é o livro "Derrubando as fortalezas em sua cidade”, organizado por Peter Wagner (1993).

${ }^{4}$ A editora da Igreja Internacional da Graça de Deus, Graça Editorial, tem publicado e distribuído, por exemplo, autores como Kenneth E. Hagin e T. L. Osborn, dois dos principais "profetas da prosperidade". 
gio dado às entidades afro como alvo preferencial para sua "guerra santa" no Brasil, enquanto que noutros fronts outras divindades de cultos distintos são atacadas, evidencia que a IURD opera com uma lógica de territorização do mal satânico em harmonia, mesmo sem tornar isso explícito, com essa doutrina. Além disso, por não negar a existência das entidades afro, por aceitar como reais os entornos simbólicos que lhes acompanham e por identificar essas entidades, não simplesmente como faces ou manifestações diversas de Satanás, mas como demônios individualizados a seu serviço (com nomes próprios, trajetórias míticas singulares, especialidades mágicas etc.), a IURD indisfarçavelmente mostra-se tributária dessa percepção teológica. Essa lógica, evidentemente, também é empregada nos outros fronts em que essa igreja esteja agindo em seu ambicioso processo de expansão.

Poderia-se objetar que esse raciocínio implica numa minimização da importância de possíveis cálculos mercadológicos feitos pelos líderes IURD quando de seus posicionamentos nos campos religiosos onde atuam, pois ao se decidirem pelo antagonismo com inimigos espirituais que gozam de familiaridade junto aos grupos sociais aos quais se dirigem, estariam tão somente atentos ao ambiente cultural envolvente, aos padrôes locais de consumo religioso, aos concorrentes na oferta por serviços mágico-religiosos e às demandas locais. Essa objeção, ao meu ver, é só em parte pertinente, pois se também é evidente o emprego de cálculos mercadológicos nos antagonismos assumidos pela IURD isso não chega a ser feito em desarmonia com as inclinaçóes teológicas por ela demonstradas. Mais prudente, portanto, seria aceitar que impera uma associação entre essas duas lógicas.

Ainda quanto à maneira como a IURD se manifesta tributária da "Doutrina dos Espíritos Territoriais" julgo necessário explicitar melhor como isso ocorre, para, então, evidenciar um possível equívoco interpretativode Jaçanã Ribeiro a respeito de como o mal satânico seria percebido pelos iurdianos.

No grande best seller do Bispo Macedo, "Orixás, caboclos e guias: deuses ou demônios”, há vários trechos que fornecem informações importan tes que permitem compreender as percepçôes demonológicas da IURD. Vejamos alguns desses trechos:

A respeito dos demônios: 
"São entidades espirituais que atuam organizadamente, atingin do e destruindo constantemente a humanidade, tendo satanás por chefe" (Macedo, 2000, p. 20)

A respeito da origem dos demônios que servem a Satanás:

"Lúcifer foi lançado por terra e trouxe consigo uma grande parte de anjos. Lúcifer se tornou diabo ou satanás e os que o acompanham tornaram-se demônios.” (Idem, ibidem, p. 22)

\section{$(\ldots)$}

A palavra anjo significa 'mensageiro'. Quando os anjos foram criados, o foram para servir a Deus, mas alguns, rebelando-se contra o Criador e seguindo Lúcifer, tornaram-se anjos decaídos, isto é, anjos desprovidos das qualidades que Deus lhes havia outorgado.

Todo o senso de bondade, de amor e de ajuda, que eles tinham, foi perdido, passando a dar lugar ao ódio, à maldade e à destruição. A Bíblia fala que eles não guardavam o seu estado original e abandonaram o seu próprio domicílio (Judas 1.6)." (Idem, ibidem, p. 24)

Percebe-se que para o Bispo Macedo há uma pluralidade de demônios que agem no mundo sob o comando de Lúcifer (Satanás ou Diabo). Esses demônios seriam anjos decaídos, tais como seu chefe, e agi riam "organizadamente" visando a destruição da humanidade. Essa percepção polidemonista, na verdade, é um dos pressupostos básicos da "Doutrina dos Espíritos Territoriais". Os que a difundem afirmam, geralmente, que esses anjos decaídos teriam, ao se tornarem demônios, se distribuído pelo mundo de forma territorialmente organizada, formando algo como jurisdiçôes culturais e/ou geográficas nas quais exercem os seus direitos de domínio. Tratam-se, portanto, de demônios no plural.

Causa-me estranheza, então, a percepção de Jaçanã Ribeiro de que a pluralidade polidemonista assumida, segundo o que se viu acima, como 
real pela IURD, seria tão somente um recurso retórico para nomear, tomando de empréstimo a variada nomenclatura alheia, a um único ser uno, o diabo Cristão. O autor parece crer, desconfio, que os iurdianos quando se utilizam daqueles vários nomes de entidades afro (Exu, Pomba-Gira, Caboclo, encosto, etc.) estão apenas fazen do uso de uma terminologia diversificada com finalidades alegóricas para nomear o Diabo ou, mais genericamente ainda, "o Mal". Nos termos do autor, "um sentido uno é imposto [pelos iurdianos] a diversidade de sentidos" encontrada no discurso dos membros das religióes afro-brasileiras a respeito de suas divindades.

É de se indagar, tendo em vista as definiçôes do Bispo Macedo antes referidas, se essa redução de sentido percebida por Jaçanã Ribeiro, ao invés de ser um exercício efetivamente produzido pelos iurdianos em relação ao repertório simbólico afro-brasileiro, não seria uma redução analítica operada pelo autor que guardaria pouquíssima correspondência com o que se pode observar atentando às posições demonológicas dessa igreja. Ao meu ver, Exu, Pomba-Gira, Bará etc. não são, no sistema iurdiano de crenças, apenas nomes diferentes que se pode atribuir ao Diabo. Ao contrário, essas entidades são percebidas como demônios reais que servem a Satanás e que têm uma existência individualizada, pessoal. Eles não são Satanás, eles são demônios. Eles não são "o Mal”, eles são promotores especializados do Mal.

Não deixa de ser interessante esse efeito polidemonizador que se produz no rastro deixado pela difusão da "Doutrina dos Espíritos Territoriais" em parte associada à expansão das crenças neopentecostais brasileiras de igrejas como a Universal do Reino de Deus. Se o campo religioso brasileiro já manifestava há muito tempo, em sua profusão polifônica, uma certa predisposição a um politeísmo popular, hoje nos deparamos com uma fragmentação pluralizadorado Mal,assistimosa uma onda de polidemonismoque inflaciona ainda mais o universo das representações populares acerca dos seres espirituais. Temos que tomar cuidado para que os tratamentos analíticosque dispensamos a essas representaçóes não obscureçam os reais contornos desses novos e/ou ressemantizados habitantes das crenças que estudamos na atualidade. $\mathrm{O}$ "Mal" pode ser analiticamente uno, mas os malvados parecem ser muitos. Não convém unificá-los artificialmente sob risco de invisibilizá-los. 


\section{REFERÊNCIAS}

DORAN, Marie-Christine. A Igreja Universal no México. In: ORO, Ari Pedro; CORTEN, André; DOZON, Jean-Pierre (Orgs.). Igreja Universal do Reino de Deus: os novos conquistadores da fé. São Paulo: Paulinas, 2003. p. 93-99.

FRESTON, Paul. A Igreja Universal na Ásia. In: ORO, Ari Pedro; CORTEN, André; DOZON, Jean-Pierre (Orgs.). Igreja Universal do Reino de Deus: os novos conquistadores da fé. São Paulo: Paulinas, 2003. p. 197-229.

JUNGBLUT, Airton Luiz. Igreja Universal do Reino de Deus no contexto do emergente mercado religioso brasileiro:uma análise antropológica. Cadernos IHU Idéias, São Leopoldo: UNISINOS, n. 36, p. 1-14, 2005.

JUNGBLUT, Airton Luiz. Os domínios do maligno e seu combate: notas sobre algumas percepções evangélicas atuais acerca do mal. Debates do NER, Porto Alegre, n. 4, p. 35-42, 2003.

MACEDO, Bispo. Orixás, caboclos e guias: deuses ou demônios?. Rio de Janeiro: Universal Produções, 2000.

MAFRA, Clara. A Igreja Universal em Portugal. In: ORO, Ari Pedro; CORTEN, André; DOZON, Jean-Pierre (Orgs.). Igreja Universal do Reino de Deus: os novos conquistadores da fé. São Paulo: Paulinas, 2003. p. 165-176.

ORO, Ari Pedro; CORTEN, André; DOZON, Jean-Pierre (Orgs.). Igreja Universal do Reino de Deus: os novos conquistadores da fé. São Paulo: Paulinas, 2003.

SEMAN, Pablo. A Igreja Universal na Argentina. In: ORO, Ari Pedro; CORTEN, André; DOZON, Jean-Pierre (Orgs.). Igreja Universal do Reino de Deus: os novos conquistadores da fé. São Paulo: Paulinas, 2003. p. 69-78.

WAGNER, C. Peter (Org.). Derrubando as fortalezas em sua cidade. Mogi das Cruzes: Unilit, 1993. 
